\title{
Antibacterial Activities of Selected Fruit Peels against Organisms Associated with Urinary Tract Infection
}

\author{
Ayuba Sunday Buru ${ }^{1,2 *}$, Ikya Homior Paschal ${ }^{1}$, Ifeanyi Tony Ojiezeh ${ }^{1}$, \\ Oluboyo Bernard Oluwapelumi ${ }^{1}$, Akele Yomi Richard ${ }^{1}$, Akinseye Janet Fumilayo ${ }^{1}$ \\ and Adewumi Ajoke Funmi ${ }^{1}$ \\ ${ }^{1}$ Department of Medical Laboratory Science, College of Medicine and Health Sciences, \\ Afe Babalola University, Ado-Ekiti, Ekiti State, Nigeria \\ ${ }^{2}$ Department of Molecular Microbiology, College of Medicine and Health Sciences, \\ Afe Babalola University, Ado-Ekiti, Ekiti State, Nigeria \\ *Corresponding author
}

\section{Ke ywords}

Antibacterial, Urinary tract infections (UTIs), Citrus sinensis and Musa paradisiacal.

\section{Article Info}

Accepted:

12 November 2016

Available Online:

10 December 2016

\section{A B S T R A C T}

The use of natural products as anti-infective agents, have given rise to new chemical diversity and are preferred in modern world. Among all these natural sources, plants and its products is more reliable because of its renewability. Urinary tract infections (UTIs) are among the most common infectious diseases occurring in either the community or healthcare setting. Orange and Plantain peels were used to determine the antibacterial activities. A measure of 50 grams of powder was filled in the thimble and extracted with $150 \mathrm{ml}$ of ethanol successively up to 48 hours. The solvent extracts were concentrated separately under reduced pressure, $2 \mathrm{~g}$ of each concentrated solvent extracts were dissolved in $20 \mathrm{ml}$ of $20 \%$ dimethyl sulphoxide and used for antibacterial assays using agar well diffusion and broth method. The phytochemical analysis of sweet orange peel shows that carbohydrate, reducing sugars, tannins and flavonoids were present, The zone of inhibition effect of the extracts on selected organism was concentration dependent $(25<50<75<100)$. Higher concentration of extract recorded larger/wider effect on each test organism. Musa paradisiacal peel showed no effect on test organism except at $100 \mathrm{mg} / \mathrm{ml}$ that recorded $4.7 \pm 0.47 \mathrm{~mm}$ against E. coli growth. The MIC and MBC of both orange peel and plantain peels suggest potency against test organisms. Orange peel has advantage over plantain peel;S. aureus, E. coli and $P$. aeruginosa were susceptible to the extract exempting $K$. pneumonia, whichshowed no susceptibility to the duo extracts. The peels of Citrus sinensis and Musa paradisiacal exhibited inhibitory activity against certain bacteria, which can be attributed to the presence of certain secondary metabolites. But when compared with standard antibiotics, the ethanoic extracts of the duo was less efficient as there was a smaller size of zone of inhibition against the luxurious growth of tested organisms.

\section{Introduction}

According to World Health Organization (WHO), medicinal plants are defined as any herbal preparations made by incorporating plant materials to its extraction, fractionation, purification, concentration, or any biological, physical processes which 
may be produced as herbal product for the immediate consumption (Alo et al., 2012).

The use of natural products as anti-microbial agents, have given rise to new chemical diversity and are preferred in modern world. The sources of these products are plants, animals and microorganisms. Among all these natural sources, plants and its products is more reliable because of its renewability. Plants are also rich in certain nutrients hence are used as sources of food and also used as pain relieve due to certain compounds which they have. From earliest times, the lack of detailed knowledge about natural product and the compounds present, their mode of action was a challenge for plants to be used for the treatment of diseases. Around the world, over the centuries different societies have developed their own traditional sense of medicinal plants and their applications.

The use of natural product for human health has been reported for a very long time, the phytochemicals from the plant extracts with known antimicrobial properties can be of great significance in the treatment of illnesses (Seenivasan et al., 2006). Secondary metabolites such as phenol compounds, tannin are well documented as part of essential oil and have shown great antimicrobial activities, these compounds can be synthesized once their active substances have elucidated (Tyagi and Malik, 2010). In controlling biofilms, the use of essential oils is highly recommended, owing to high effective diffusion and mode of contact (Al-Shuneigat et al., 2005). Therefore, the essential oils and other promising plants extracts have aroused interest as sources of natural products. Their exploration as potential alternative remedies for the treatment of various infectious diseases cannot be underscore (Tepe et al., 2004; Dorman and Deans, 2000).
Urinary tract infections (UTIs) account for most of the common infectious diseases found within the community or healthcare setting (Nicolle et al., 2005).

In empirical antimicrobial treatment in both primary and secondary care setting, UTIs are the commonest clinical indication, and urine samples usually constitute the single largest category of specimens examined in most medical microbiology laboratories (Morgan, 1993). Uncomplicated UTIs typically occur in healthy adult nonpregnant woman, while complicated UTIs (cUTIs) may occur in all gender and age groups and are frequently associated with either structural or functional urinary tract abnormalities.

Examples include foreign bodies such as calculi (stones), indwelling catheters or other drainage devices, obstruction, immunosuppression, renal failure, renal transplantation and pregnancy (Lichtenberger and Hooton, 2008). UTI in the elderly is almost always complicated in men with prostatic hypertrophy and in postmenopausal women who may have an increased post-void residual volume (Nicolle, 2001). The likelihood of treatment failure and serious complications, particularly the development of antimicrobial resistance, is more common in complicated UTI.

Although a broad range of pathogens can cause complicated UTI, E. coli remains the most common; however, even this organism is becoming resistant to the agents that are normally prescribed (Nicolle, 1997).This study is aimed at investigating the antibacterial activities of some natural plant extracts against organisms associated with urinary tract infection. 


\section{Materials and Methodology}

\section{Collection of Plant Materials}

Plantain and sweet orange were obtained from Sabo market in Ado-Ekiti. The plant materials were washed with water thoroughly, air dry and peeled. The peels were shade dried in medical laboratory department for about three weeks and a further three days drying in the oven at a temperature of $37^{\circ} \mathrm{C}$ and were grounded to fine powder and store away from sunlight.

\section{Test Microorganisms}

Pure cultures of pathogenic bacteria that are associated with urinary tract infection (UTI) were obtained from the Department of Medical Microbiology and Parasitology, Ekiti State University Teaching Hospital. The bacteria isolates include Escherichia coli, Pseudomonas aeruginosa, Klebsiella pneumoniae and a gram positive bacteria, Staphylococcus aureus. The test organisms were sub cultured into nutrient agar slant and stored at $4^{\circ} \mathrm{C}$ until when required for use.

\section{Preparation of ethanolic extract}

A measure of 50 grams of powder was filled in the thimble and extracted with $150 \mathrm{ml}$ of ethanol successively up to 48 hours. The solvent extracts were concentrated separately under reduced pressure using method described by Harborne (1992). Extract from this method was weighed and stored at $4^{\circ} \mathrm{C}$ in a refrigerator until required. After complete solvent evaporation, 2 gram of each concentrated solvent extracts were dissolved in $20 \mathrm{ml}$ of $20 \%$ dimethyl sulphoxide and used for antibacterial assays.

\section{Test for Phytochemicals}

Test for carbohydrate (Molisch's test), Reducing sugars (Fehling's test), Tannins
(Gelatin test), Flavonoid, Terpenes (Salkowski test) and Saponinwere carried out using standard method as described by Aboh et al., (2014).

\section{Preparation of Test Isolates and Standardization}

The preserved test organisms were subcultured on nutrient agar and incubated overnight to obtain discrete colonies. A colony were picked and inoculated in peptone water and incubated for 18 to 24 hours. The overnight culture broth was then compared and was adjusted to match that of $0.5 \mathrm{McF}$ arland standard $\left(10^{5} \mathrm{CFU} / \mathrm{mL}\right)$ by diluting it with distill water.

\section{Testing Assay}

Preparation of Nutrient Agar and Well Diffusion Susceptibility Test

In the preparation, appropriate quantity was weighed following the manufacturer's instruction, dissolved in distilled water, mixed thoroughly and sterilized at $121^{\circ} \mathrm{C}$ (15 lbs of pressure) for 15 minutes. It was then allowed to cool to a temperature of $50^{\circ} \mathrm{C}$, poured into petri dishes, allowed to solidify Well diffusion, several punched holes were made on the agar plate, seeded the test isolate on the medium and holes were filled with varying concentrations of the test extract. It was then incubated at $37^{\circ} \mathrm{C}$ for 18 hours and inhibition zones measured in millimeters (Cheesbrough, 2000)

\section{Minimum Inhibitory Concentration and Minimum Bactericidal Concentration}

Minimum inhibitory concentration was carried out using standard methods as described by Cheesbrough (2000). 


\section{Results and Discussion}

The phytochemical analysis of sweet orange peel shows that carbohydrate, reducing sugars, tannins and flavonoids were present while terpenes and saponins were completely absent. Plantain peels, yield carbohydrate, reducing sugars and tannins that are present (table 1).

The effects of $C$. sinensis on zone of inhibition of selected organisms are shown on table 2. The effect was concentration dependent $\quad(25<50<75<100) . \quad$ Higher concentration of extract recorded larger/wider (zone of inhibition (mm) on each test organisms. Musa paradisiacal peel showed no effect on test organism except $100 \mathrm{mg} / \mathrm{ml}$ of extract that recorded $4.7 \pm 0.47 \mathrm{~mm}$ against $E$. coli growth (Table 3). The MIC and MBC of both orange peel and plantain peels are shown on table 4.Orange peel has more inhibitory effect over plantain peels: S. aureus, E. coli and $P$. aeruginosa were susceptible to the extract except $K$. pneumonia, which showed no susceptibility to the duo extracts.

Medicinal plant and aromatic compounds had been found to be sources of bioactive component that are responsible for inhibiting bacterial pathogens (Bruneton, 1995). Enormous research has been carried out to determine the substances that have the capacity to inhibit pathogens growth without favoring the toxic effect towards the host cell. Many studies have reported the potential antibacterial activities of medicinal plant including tropical fruits peels such as sweet orange, banana and a host of others (Karuppiah and Mustaffa, 2013). Although some of the antibacterial activities of medicinal plant are well-documented, their antibacterial capacity invitro may have a wide degree of variation depending on several factors such as test medium, the method employed, test organism and the difference in nature of the plants and plant products (Fagbemi et al., 2009). Ekwenye and Edeha (2010) reported antibacterial activity of the ethanol and aqueous extract of Citrus sinensis leaf against E.coli, But when compared with the ethanoic extract from the orange peel, the peel was more efficient against test organisms, the variance may not be unconnected to difference in the phytochemical composition in various part of the plant, the extraction methods used, environmental factors and difference in the genotypes of the citrus plant used.

Antimicrobial properties of extract are primarily related to its phenol compounds. Whatever phenol substances in the extract is much higher, their antimicrobial properties is more (Kim et al., 1995). The phytochemical analysis of the peel of citrus revealed that secondary metabolites such as tannins, terpenoids, alkaloids and flavonoids that are known to have antimicrobial properties. The structure and functional properties of lipid fraction of the plasma membranes of bacteria and yeasts are affected bymonoterpenes thereby causing leakage of intercellular material and expulsion of critical molecules and ions leading to death of microbes. Terpenoids inhibits microbial respiratory oxygen enzymes uptake and oxidative phosphorylation (Cox et al., 2000 and Trombette et al., 2005). Charis et al., (2004) in a research showed that different citrus have different effects on different bacteria. Antimicrobial properties of oils extracted from the citrus peel it is directly affected by its constituents. Essential fatty acids and alkaloids, lactone, polyacetylene are compounds effective on different bacteria. The antimicrobial effect of citrus depends on so many factors which include soil separation, harvesting season, the extraction process and the type of bacteria. 
Orange peel extract showed inhibitory activity against all the pathogens tested with exception of $K$. pneumoniae while the plantain peel extract had effect only on $E$. coli. This observation is in tandem with the report of Nannapaneni et al., (2008) who showed that natural compounds of Citrus sinensis peel had inhibitory effects on different strains of Escherichia coli, Salmonella and some food pathogenic bacteria. Citrus sinensis peel extracts had significant antimicrobial effects on gram positive and gram negative bacteria. The ethanolic extraction from orange peel had inhibitory effect on Gram positive and gram negative bacteria exempting $K$. pneumonia. This report corroborate with the earlier report of Omodamiro and Umekwe (2013) and Khushwaha et al., (2012), respectively. It was also observed that the degree of susceptibility was concentration dependent, the higher the concentration the larger/wider the size of zone of inhibition likewise the lower concentrations. However, Madhuri et al., (2014) documented that methanol extract showed inhibitory effect on tested pathogens including $K$. pneumonia which is at variance with the result obtained in this study. The extract from Musa paradisiacal show no significant inhibitory activity on most of the tested organisms, except $E$. coliwhich might be as a result of low concentration of hydrocarbons, monoterpene and oxygenated monoterpenes and other valuable phytochemicals that seems to be tolerable to the tested organisms. The observation from this study is in agreement with Chabuck et al., (2013) who also reported insignificant inhibitory activities of Musa paradisiaca on E. coli, but contradict the work of Igadharo (2012), Okechukwu (2012), Ehiowemwenguan et al., (2014) and Akhraiyi et al., (2016) who in their various reports indicated that Plantain peel had significant inhibitory activities on test organisms of both gram positive and gram negative bacteria.

Table.1 Phytochemical Analysis of Ethanol Extract of Sweet orange And Plantain Peels

\begin{tabular}{|l|l|l|}
\hline Phytochemical & Orange & Plantain \\
\hline Carbohydrate & + & + \\
\hline Reducing sugars & + & + \\
\hline Tannins & + & + \\
\hline Flavonoids & + & \\
\hline Terpenes & - & - \\
\hline Saponin & - & - \\
\hline
\end{tabular}

Key: $(-)=$ Negative $\quad(+)=$ Positive

Table.2 Antibacterial Activity of Ethanol Extract of Citrus sinensis Using Agar Well Diffusion Method

\begin{tabular}{llllllll}
\hline Organism & \multicolumn{3}{c}{ Concentration $\mathbf{( m g / m l )}$} & \multicolumn{4}{c}{ Control Antibiotics } \\
\hline & 25 & 50 & 75 & 100 & Augumentin & Gentamycin & Cotrimodaxole \\
\hline S.aureus & $7.7 \pm 1.60$ & $13.7 \pm 4.64$ & $18 \pm 4.24$ & $22 \pm 4.97$ & $25 \pm 4.87$ & $28 \pm 4.47$ & $25 \pm 4.87$ \\
E.coli & NS & NS & $6.7 \pm 2.91$ & $10.7 \pm 2.70$ & NS & $22 \pm 4.97$ & $33 \pm 5.97$ \\
K.pneumoniae & NS & NS & NS & NS & $24 \pm 4.37$ & $19 \pm 4.77$ & NS \\
P.aeruginosa & NS & $2.3 \pm 2.05$ & $7 \pm 1.41$ & $10.7 \pm 1.63$ & $22 \pm 4.97$ & NS & $10 \pm 4.47$ \\
\hline
\end{tabular}

Key: $N S=$ Not Sensitive, Mean \pm SD, Values (Mean \pm SD) of 3 Samples Test 
Table.3 Antibacterial Activity of Musa Paradisiacal Peel Extract Using Agar Well Diffusion Method

\begin{tabular}{llllllll}
\hline Organism & \multicolumn{9}{c}{ Concentration $(\mathbf{m g} / \mathbf{m l})$} & \multicolumn{2}{c}{ Control Antibiotics } & \\
& 25 & 50 & 75 & 100 & Augmentin & Gentamycin & Cotrimodaxole \\
\cline { 2 - 7 } S. aureus & NS & NS & NS & NS & $25 \pm 4.97$ & $28 \pm 4.87$ & $25 \pm 4.97$ \\
E.coli & NS & NS & NS & $4.7 \pm 0.47$ & NS & $22 \pm 4.97$ & $33 \pm 5.67$ \\
K.pneumonia & NS & NS & NS & NS & $24 \pm 4.88$ & $19 \pm 4.67$ & NS \\
P.aeruginosa & NS & NS & NS & NS & $22 \pm 4.97$ & NS & $10 \pm 4.37$ \\
\hline
\end{tabular}

Key: $\quad$ NS $=$ Not Sensitive, Mean \pm SD, Values (Mean \pm SD) Of 3 Samples Test

Table.4 Showing Minimum Inhibitory Concentration and Minimum Bactericidal Concentration of Orange and Plantain Peel Extract

\begin{tabular}{lllll}
\hline Organism & \multicolumn{2}{l}{ Orange $(\mathbf{m g} / \mathbf{m l})$} & \multicolumn{2}{l}{ Plantain(mg/ml) } \\
\cline { 2 - 5 } & MIC & MBC & MIC & MBC \\
\hline S. aureus & $7 \pm 2.97$ & $25 \pm 4.87$ & NS & NS \\
E. coli & $14 \pm 4.25$ & $50 \pm 5.67$ & $25 \pm 4.87$ & $50 \pm 5.67$ \\
P. aeruginosa & $50 \pm 5.67$ & $14.5 \pm 4.35$ & NS & NS \\
\hline
\end{tabular}

Key: $\quad$ NS $=$ Not Sensitive, MIC $=$ Minimum Inhibitory Concentration, $\mathrm{MBC}=$ Minimum Bactericidal Concentration

The variation is these reports could be as a result of harvesting, storage and processing methods used. The genotypes of the test organisms could also be a serious factor to be considered. In general, the result obtained from $C$. sinensis peels correlates with the reports of earlier scientists, though differences with test isolate of $K$. pneumonia which might probably be due the quantity of the constituent that seemsnon-toxic to this organism. Meanwhile, these extracts exhibit potent antibacterial activity on the tested organisms but, when compared with standard antibiotics, the ethanoic extracts of the duo was less efficient as there was a smaller size of zone of inhibition against the luxurious growth of tested organisms.
In conclusion, the peels of most fruits are considered to be a waste by processing industries. The peels of Citrus sinensis and Musa paradisiacal exhibited inhibitory activity against certain bacteria, which can be attributed to the presence of certain secondary metabolites. It is however suggestive that these fruits peels can be of medicinal value. Although when the efficacies of these peels are compared, sweet orange peels exhibited a better inhibitory activity against bacterial associated with Urinary tract infection.

\section{Conflict of interest}

No conflict of interest expressed 


\section{Acknowledgement}

I sincerely wish to express my deepest gratitude and appreciation to $\mathrm{Mr}$. Amos (Biochemistry Department) College of sciences for helping with the extraction process, Miss Ogunbola Ogunfolakun Omobolake and entire staff members and students of the department of Medical Laboratory Science, Afe Babalola University, Ado-Ekiti, without which this work would not have made this study possible.

\section{References}

Aboh, M.I., Olayinka, B.O., Adeshina G.O., Oladosu, P. 2014. Antifungal Activities of Phyto Compounds from Mitracarpusvillosus (Sw.. DC from Abuja, Nigeria, J. Microbiol. Res., 4(2): 86-91.

Akharaiyi, F.C., Asoso, o.s. and Animba, L.S. 2016. Antibacterial activities of plantain (Musa paradisiacal. peel and fruit. Der Pharmacia Lettre, 5(5): 5-11.

Alo, M. N., Anyim, C., Igwe, J. C., Elom, M. and Uchenna, D.S. 2012. Antibacterial activity of water, ethanol and methanol extracts of Ocimum gratissimum, Vernonia amygdalina and Aframomum melegueta, Adv. Appl. Sci. Res., (2):844848

Al-Shuneigat, J., Cox, S.D. and Markham, J.L. 2005. Effects of a topical essential oilcontaining formulation on biofilmforming coagulase-negative staphylococci. Lett. Appl. Microbiol., 41, $52-55$.

Bruneton, J. 1995. Pharmacognosy, phytochemistry, medicinal plants: Lavoisier publishing.

Chabuck, Z.G., Al-Charrakh, A. H., Nada, K. K. H. and Shatha, K. K (2013. Antimicrobial Effect of Aqueous Banana Peel Extract, Iraq.Research Gate: Pharmaceutical Sci., 1: 73-75.

Charis, K. 2000. Feed Mix (special issue on Nutraceuticals), 19-21.
Cheesbrough, M. 2000. Microbiological test: District Laboratory Practice in Tropical Countries. In: Cremer, A. and Evan, G. eds. Cambridge University Press, UK. Pp: $1-226$.

Cox, S.D., Mann C.M., Markham, J.L., Bell, H.C., Gustafson, J.E., Warmonrton, J.R. and Wyllie, S.G. 2000. The mode of antibacterial action of essential oil of MelaleucaAlternifolia (tea tree oil). $J$. Appl. Microbiol., 88: 170-175.

Dorman, H.J.D. and Deans, S. G. 2000. Antimicrobial Agents from Plants: Antibacterial Activity of Plant Volatile Oils. J. Appl. Microbiol., 88: 308-316.

Ehiowemwenguan, G., Emoghene, A. O. and Inetianbor, J.E. 2014. Antibacterial andphytochemical analysis of Banana fruit peel. IOSR J. Pharmacy, 4(8): 18-25

Ekwenye, U.N. and Edeha, O.V. 2010. The antibacterial activity of crude leaf extract of Citrus sinensis (sweet orange). Int. J. Pharmaceutical and Biol. Sci., 1(4): 742750.

Fagbemi, J.P., Ugoji, E., Adenipekun, T. and Adelowotan, O. 2009. Evaluation of the antibacterial properties of unripe banana (Musa sapientum L.), lemon grass (Cymbopogoncitratus S. and turmeric (Curcuma longa L.. on pathogens. African J. Biotechnol., 8(7): 1176-1182

Harborne, J.B. 1992. Phytochemical methods. Chapman and Hall publications, London, pp: 7-8.

Ighodaro, O.M. 2012. Evaluation study on Nigerian species of Musa paradisiaca Peels: Phytochemical screening, Proximate analysis, Mineral Composition and Antimicrobial Activities. Researcher, 4(8):17-20.

Karuppiah, P., Mustaffa, M. 2013. Antibacterial and antioxidant activities of $<\mathrm{i}>$ Musa $</ \mathrm{i}>$ sp. Leaf extracts against multidrug resistant clinical pathogens causing nosocomial infection. Asian Pacific $J$. Trop. Biomed., 3(9): 737-742.

Khushwaha, A., Singh, R. P., Gupta, V. and Singh, M. 2012. Antimicrobial properties of peels of Citrus fruits. Int. J. Universal Pharmacy and Life Sci., 2(2): 24-38. 
Kim, J.M., Marshall, J.A., Cornell, J.A. and Preston, J.F. 1995. General and introductory food science and technology. J. Food Sci., 60(6): 1364 1368.

Lichtenberger, P., Hooton, T.M. 2008. Complicated urinary tract infections. Curr. Infect. Dis. Rep., 10: 499504.

Madhuri, S., Ashwini, U., Srilakshmi, N.S. and Prashith-Kekuda, T.R. 2014. Antimicrobial activity of Citrus sinensis and Citrus aurantium peel extracts. $J$. Pharmaceutical and Scientific Innovation, 3(4): 366-368

Morgan, M.G. and McKenzie, H. 1993. Controversies in the laboratory diagnosis of community acquired urinary tract infection. European J. Clin. Microbiol. Infect. Dis., 12, 491-504.

Nannapaneni, R., Arunachalam, M., Crandall, G. P., Michael G. Johnson, O'Bryan, C. A., Chalova, V. I., Callaway, T. R., Carroll, J. A., John, D. A., David, J. N. and Steven, C.R. 2008. Antimicrobial Activity of Commercial Citrus-Based Natural Extracts against Escherichia coli 0157:117 Isolates and Mutant Strains. Foodborne pathogens and dis., 5(5), 695699.

Nicolle, L.E. 1997. Asymptomatic bacteriuria in the elderly. Infect. Dis. Clin. North Am., 11: 647-62.

Nicolle, L.E. 2001. A practical approach to the management of complicated urinary tract infection. Drugs Aging, 18: 243-54.

Nicolle, L.E., Bradley, S., Colgan, R., Rice, J.C., Schaeffer., A., Hooton, T.M., et al. 2005. Infectious Diseases Society of America guidelines for the diagnosis and treatment of asymptomatic bacteriuria in adults. Clin. Infect. Dis., 40, 643-654.

Okechukwu, R.I., Onyedineke, N.E., Mgbemena, I.C., Opara, F.N. and Ukaoma, A.A. 2012. Inhibition of Pathogenic Microorganisms by Ethnobotanical Extracts of Fruit Peels of Musa paradisiacal. J. Appl. Pharmaceutical Sci., 2(4): 01-03.

Omodamiro, O.D. and Umekwe, J.C. 2013. Evaluation of anti-inflamatory, antibacterial and antioxidant properties of ethanolic extracts of Citrus sinensis peel and leaves. J. Chem. Pharmaceutical Res., 5(5): 56-60.

Seenivasan, P., Manickkam, J. and Savarimuthu, I. 2006. In vitro antibacterial activity of some plant essential oils. BMC Complement. Altern. Med., 6: 1-8.

Tepe, B., Daferera, D., Sokmen,M., Polissiou, M. And Sokmen, A. 2004. In vitro antimicrobial and antioxidant activities of the essential oils and various extracts of Thymus eigii. J. Agric. Food Chem., 52: 1132-1137.

Trombetta, D., Castelli, F., Sarpietero, M.G., Venuti, V., Cristani, M., Daniele, C., Sajja, A., Mazzanti, G., and Bisignano, G. 2005. Mechanisms of antibacterial action of three monoterpenes. Antimicrobial Agents and Chemother., 49: 2472-2478.

Tyagi, A.K., Malik, A. 2010. Liquid and vapourphase antifungal activities of selected essential oils against Candida albicans: microscopic observations and chemical characterization of Cymbopogon citratus. BMC Complement Altern. Med., 10: 65.

\section{How to cite this article:}

Ayuba Sunday Buru, Ikya Homior Paschal, Ifeanyi Tony Ojiezeh, Oluboyo Bernard Oluwapelumi, Akele Yomi Richard, Akinseye Janet Fumilayo and Adewumi Ajoke Funmi. 2016. Antibacterial Activities of Selected Fruit Peels against Organisms Associated with Urinary Tract Infection. Int.J.Curr.Microbiol.App.Sci. 5(12): 265-272.

doi: http://dx.doi.org/10.20546/ijcmas.2016.512.028 